\title{
Editorial
}

\section{Thinking and Feeling with the Church (Sentire Cum Ecclesia)}

\author{
Susan K. Wood \\ Marquette University, Wisconsin, USA \\ susan.wood@marquette.edu
}

In the sixteenth century, St. Ignatius of Loyola (1491-1556), the founder of the Society of Jesus, developed eighteen rules for 'thinking with the church' (sentire cum ecclesia) in his Spiritual Exercises. In many ways, it is an odd list that gives witness to its post-Reformation provenance. It includes such things as commending the confession of sins to a priest and frequent assistance at mass, approval of religious vows, veneration of relics, abstinence and fasts, and not speaking of predestination frequently. The historian reads these against the predestination of Calvin's doctrine, Luther's critique of monasticism, and the Reformation criticism of masses offered for the dead. Less obviously timebound and more at the core of the concept are the injunctions to value highly sacred teaching and to be of the same mind and in conformity with the Church herself. Even more personally, sentire cum ecclesia is interpreted today as feeling with the church and as loving the church.

To feel with the church in these days of ecclesiastical political intrigue and of the crisis of sexual abuse and its mishandling by bishops and cardinals is to feel pain, rage, and shame. What does it mean to 'feel with the church and to love the church' when the institution of the church and a number of those who officially represent her fail to protect the vulnerable, when bishops cross the line of partisan politics, when rich interest groups lobby church leaders in the same way that they lobby government officials, and when the ecclesial fabric is torn asunder by fractious groups, each claiming to speak for the church? 
Pope Francis, good son of Ignatius that he is, provides a twenty-first century interpretation of the principle. When asked in an interview by Antonio Spadaro what sentire cum ecclesia means to him, Pope Francis answered with the image of the Church from the Second Vatican Council and Lumen gentium 12, the holy, faithful people of God: 'The people themselves are the subject. And the church is the people of God on the journey through history with joys and sorrows. Sentire cum Ecclesia [to think and to feel with the church], therefore, is my way of being a part of this people.' ${ }^{1}$ Francis then developed the idea of the infallibility in believing through a supernatural sense of the faith of all the people walking together. His 'thinking with the church' involves a dialogue among the people and the bishops and the Pope. For him, 'this church with which we should be thinking and feeling is the home of all, not a small chapel that can only hold a small group of select people.' ${ }^{2}$ The church is all the people of God, not just those in ecclesiastical offices. Thus, to feel with the church is to feel its pain as well as its joys. The church is a field hospital where ministers accompany sinners and heal wounds. Structural and organizational aspects of the church and their reform are secondary to this primary work of mercy. For Francis, the ecclesiastical man is not a bureaucrat, but a pastor, 'able to support the movement of God among their people with patience, so that no one is left behind. ${ }^{3}$ This is why his priority is to for the gospel to be 'simpler, profound or, more radiant', for once people rediscover the immediacy of the gospel, moral consequences will then follow. ${ }^{4}$

Perhaps the malady afflicting the church most profoundly is amnesia. Too many within it, including its ministers, have forgotten the power of the gospel. Taking their eyes off Christ, too many of its members have been caught up in the culture wars, politicizing intramural disputes and weaponizing the abuse crisis in the name of those culture wars in the quest for power and prestige.

When Pope Francis went to the General Congregation of the Jesuit order on 24 October 2016 he outlined three areas of the Society's path into the future which provide guidance to the whole church in its path through its contemporary crisis. He said that the graces for which each Jesuit and the whole Society

1 Pope Francis with Antonio Spadaro, My Door is Always Open, trans. Shaun Whiteside (London: Bloomsbury, 2014), p. 49.

2 Ibid., p. 51.

3 Ibid., p. 55 .

4 Ibid., p. 58. 
must always ask are consolation, compassion, and discernment. ${ }^{5}$ He urged Jesuits to be not 'clerical' but 'ecclesial'.

Consolation rooted in prayer is certainly needed these days, not just to comfort an afflicted church, the faithful people of God, but because the task of evangelization requires that the Good News be announced in joy rather than sadness. Consolation is needed so that we do not 'despair in the face of the world's evils' or the sinfulness of the church's members and leaders. For Francis, joy is 'a clear indication of grace, it shows that love is active, at work, present'.

Second, Francis invites us 'to allow ourselves to be moved by the Lord on the cross'. This means getting close to the vast numbers of men and women who suffer and offering various services of mercy to them. Mercy is a lifestyle, not an abstract concept. In drawing close to those who suffer, we are in touch with the people of God and thus with the suffering church. We do this by first recognizing that we ourselves are touched by God's mercy: 'Only if we experience this healing power first-hand in our own wounds, as individual persons and as a body, will we lose the fear of letting ourselves be moved by the immensity of our brothers' and sisters' suffering. Only thus will we set ourselves to walk patiently with our people, learning from them the best way of helping and serving them.' This recognition of our need for mercy and of how we have received mercy, as described by Pope Francis, cannot arise from a position of power and entitlement or - to use Pope Francis' phrase, borrowed from Henri de Lubac - 'spiritual worldliness', but only from a posture of humility. ${ }^{6}$

Finally, 'to think and feel with the church' requires discernment, so that we speak and act with the 'good spirit'. Thinking with the church, 'without losing peace and with joy, considering the sins we see, in us as well as in others, and in the structures that we have created, involves carrying the cross and experiencing poverty and humiliation'. It also requires acting against an anti-ecclesial spirit which cuts us off from others. A real ecclesiastic walks with a heart that beats to the rhythm of a journey undertaken together with all the faithful people of God'?

Thinking and feeling with the church poses considerable challenges at this time in the church when some ecclesial commentators wonder whether the

5 Discourse of the Holy Father Francis to the members of the $36^{\text {th }}$ General Congregation of the Society of Jesus. http://gc36.org/wp-content/uploads/2016/10/20161024_Discourse_Pope_ GC36_EN.pdf.

6 Pope Francis, Evangelii Gaudium, 24 November 2013, §§ 93-97; Henri de Lubac, The Splendor of the Church (San Francisco: Ignatius Press, 1999), pp. 241-257.

7 Francis, Homily at the Church of the Gesu, 3 January 2014. 
church is on the brink of a new schism. Pope Francis' approach as sketched out here really amounts to a return to the basics, which means a return to the gospel in solidarity with the people of God. In Evangelii Gaudium he invited 'all Christians, everywhere, at this very moment, to a renewed personal encounter with Jesus Christ, or at least an openness to letting him encounter them.' ${ }^{8}$ This cannot be done apart from solidarity with the people of God who make up the members of the body of Christ. Nothing short of this will heal the church's divisions.

8 EG 3. 